\title{
PRESS RELEASES
}

\section{Audit of local government-owned companies}

\author{
ANTO Bajo, PHD, Institute of Public Finance, Zagreb \\ MARKO PRIMORAC, PHD, Faculty of Economic and Business, Zagreb
}

The Report on the audit of efficiency in achieving results and accomplishing business goals of companies owned by local and regional governments, performed by the State Audit Office, is in the parliamentary procedure. The audit covered 92 local government-owned companies in 20 counties (excluding the Gity of Zagreb) for the period 20Io-12. The State Audit Office (SAO) found that the companies were insufficiently effective in achieving their results and accomplishing their business goals. Although useful, the SAO's Report could have a very limited impact on the change of the companies' status, improvement of public services and financial management of local government units.

The objectives and criteria are numerous, but the purpose is unclear. The audit covered the activities of selected local government-owned companies related to the evaluation of the setting of business goals, business performance measurement and the achievement of the intended purpose of establishment. As many as 25 different criteria were used in the auditing process. Despite the effort made to perform the audit, the effect of the Report on the financial management of local government units is questionable.

Criteria for the efficiency audit. The first two areas of audit - the setting of business goals and business performance measurement- mainly deal with administrative aspects (the contents of various plans, reports, etc.). The third area - the achievement of the intended purpose of establishing companies - is based on criteria that are far more significant for the local government units' operations. These criteria are used to check whether the companies have performed the activities for which they are registered, whether they fulfil their tasks and main objectives, whether their own revenues are sufficient to fund the operations, whether their business results allow them to perform the tasks and achieve goals for which the companies were founded without the financial support of the founders, whether those companies receive subsidies from local government budgets and spend them for predetermined purposes, whether expenditures are used for the realization of basic business objectives (purposes), whether the achieved results are satisfactory and how those companies perform in terms of their success indicators compared to earlier periods.

Questionable choice and scope of companies. ${ }^{.}$The audit covered companies in 20 counties, but the company Zagreb Holding - by far the largest local utility company - was left out of the scope. The selection criteria for companies covered by the audit were not clear enough. It would have been better if the SAO had carried out an audit of utility companies only, or at least part of them (for example local transportation companies). Unfortunately, local utility companies were practically excluded from the audit. However, the audit revealed a lot of useful facts and information. Local government units own companies engaged in promoting regional development, managing business zones, attracting investments,

I The document titled "The database of companies owned by local and regional governments", containing a list of more than 700 companies and various institutions, is available on the website of the Ministry of Finance. 
developing projects and drawing out business, development, investment and other plans. Local government units even possess companies engaged in commercial mediation, waste management, physical culture, asset management, consolidated collection of utility fees, radio programme production and broadcasting, as well as publishing and printing activities. The scope and type of activities (generally inherent to the private sector) pursued by companies owned by local government units is, in fact, incredible. The question is why local government units actually own these companies.

Improving the content of the Report. The publication of the criteria used for selecting companies for the efficiency audit would contribute to the credibility of the Report. Data on the size of the entire local government-owned companies sector would be significant for getting an impression of what part of the sector is covered by the audit. The Report would also benefit from data on the administrative status of the owner (a county, city or municipality), size of the share in a company (majority or minority) and type of activity a particular local government-owned company performs. Under a uniform approach, the SAO treated retail markets, radio stations, development agencies, bookkeeping offices, construction companies and sports associations in the same way. Too many different companies dependent on local government budgets pose a significant threat to the stability of local finances. This is confirmed by the data on the amount of subsidies those companies receive from local government budgets.

Subsidies from local government budgets. Companies covered by the audit received HRK $244.6 \mathrm{~m}$ (23.2\% of their total revenues) in subsidies from local government budgets. Out of 92 companies, only I4 operated without the financial support of the founder. Subsidies accounting for over $99 \%$ of total revenues were reported by the Waste Management Agency Ltd., Dubrovnik (99.9\%), Eko Ltd., Zadar (99.7\%), Eko-Start Ltd., Sisak (IOo\%), Power Plant Vinkovci Ltd., Vinkovci (99.9\%), Krapina-Zagorje Airport Ltd., Zabok (99.8\%), Petrinja Development Agency, Petrinja (99.2\%) and Sisak Projects Ltd., Sisak (99.1\%). It is reasonable to question why these companies do not operate within local budgets.

Irregularities and omissions in setting business objectives were found in 83 out of 92 companies covered by the audit. Companies failed to define their missions and visions, determine their strategic goals or adopt strategic (long-term) development plans. As many as 59 companies did not have strategic plans, whereas 16 companies failed to adopt annual work programs and business plans. In terms of business performance measurement, irregularities and omissions were found in 86 companies. As many as 7 companies did not even prepare annual reports. Financial results in ledgers and financial statements of some companies were not realistically presented due to improper recording of loan repayment subsidies and the failure to account for depreciation and impairment of outstanding claims. All the above findings clearly indicate the need for serious reconstruction and a change of the status of most local government-owned companies, as well as for possible changes in their funding logic.

The intended purpose of establishment has not been achieved in I6 companies. ${ }^{2}$ In addition, 45 companies failed to arrange their business financing with the founders, whereas 36 companies failed to achieve satisfactory operating results and performance indicators. Certain companies failed to spend all capital subsidies received from their founders for the intended purposes. Some companies calculated and paid out salaries to their directors in amounts higher than those specified in the founders' guidelines. Moreover, companies paid out fees to employees, contrary to their founders' suggestions. Such companies have often received subsidies from local government budgets, and should therefore be restructured or privatized, because they pose an unnecessary financial burden on their owners.

Despite its questionable purpose, the audit performed is extremely useful because it highlights the problem of too many different companies owned by local government units. From the findings of the SAO it is obvious that most companies should be privatized, part of them should be included in local government budgets, and the rest (mostly utility companies) should maintain the status of local government-owned companies. Regardless of their future status, the SAO should perform a detailed financial and efficiency analysis of all companies owned by all local government units. There are no professional or formal legal obstacles to such an approach.

${ }^{2}$ These are: Eko Ltd., Zadar, Eko-Start Ltd., Sisak, Eko-System Ltd., Vukovar, Power Plant Vinkovci Ltd., Vinkovci, Economic Zone Prelog Ltd., Prelog, Krakom-Construction Ltd., Krapina, Krapina-Zagorje Airport Ltd., Zabok, Kukavica Ltd., Velika Pisanica, Međimurje Energy Agency - Menea Ltd., Čakovec, Međimurje Entrepreneurship Fair - Mesap Ltd., Nedelišće, Entrepreneurship Centre Beli Manastir Ltd., Beli Manastir, Entrepreneurship Incubator Ltd., Zadar, Regional Centre of Clean Environment Ltd., Split, Trg Ltd., Koprivnica, Wholesale of Fish Poreč Ltd., Poreč, Viroexpo Ltd., Virovitica. 